Research article

\title{
A case-control study of the HER2 Ile655Val polymorphism in relation to risk of invasive breast cancer
}

\author{
Stephanie E Nelson ${ }^{1}$, Michael N Gould ${ }^{1,2}$, John M Hampton ${ }^{3}$ and Amy Trentham-Dietz ${ }^{3,4}$
}

\author{
${ }^{1}$ McArdle Laboratory for Cancer Research, University of Wisconsin, Madison, Wisconsin, USA \\ ${ }^{2}$ Department of Oncology, University of Wisconsin, Madison, Wisconsin, USA \\ 3University of Wisconsin Comprehensive Cancer Center, Madison, Wisconsin, USA \\ ${ }^{4}$ Department of Population Health Sciences, University of Wisconsin, Madison, Wisconsin, USA \\ Corresponding author: Amy Trentham-Dietz, trentham@wisc.edu
}

Received: 30 Jul 2004 Revisions requested: 1 Sep 2004 Revisions received: 14 Jan 2005 Accepted: 26 Jan 2005 Published: 11 Mar 2005

Breast Cancer Research 2005, 7:R357-R364 (DOI 10.1186/bcr1004)

This article is online at: http://breast-cancer-research.com/content/7/3/R357

(c) 2005 Nelson et al.; licensee BioMed Central Ltd.

This is an Open Access article distributed under the terms of the Creative Commons Attribution License (http://creativecommons.org/licenses/by/ 2.0), which permits unrestricted use, distribution, and reproduction in any medium, provided the original work is properly cited.

\begin{abstract}
Background Overexpression of the HER2 proto-oncogene in human cancer cells has been associated with a poor prognosis, and survival improves with therapy targeting the HER2 gene. Animal studies and protein modeling suggest that the lle655Val polymorphism located in the transmembrane domain of the HER2 protein might influence breast cancer development by altering the efficiency of homodimerization.
\end{abstract}

Methods To investigate this genetic polymorphism, incident cases of invasive breast cancer $(N=1,094)$ and population controls of a similar age $(N=976)$ were interviewed during 2001 to 2003 regarding their risk factors for breast cancer. By using DNA collected from buccal samples mailed by the participants, the HER2 Ile655Val polymorphism was evaluated with the Applied Biosystems allelic discrimination assay. Odds ratios (ORs) and 95\% confidence intervals (95\% Cls) were estimated by logistic regression adjusted for numerous breast cancer risk factors. Analysis was restricted to women with selfreported European descent.

Results Prevalence of the $\mathrm{Val} / \mathrm{Val}$ genotype was $5.6 \%$ in cases and $7.1 \%$ in controls. In comparison with the lle/lle genotype, the lle/Val genotype was not significantly associated with breast cancer risk (OR $0.97,95 \% \mathrm{Cl} 0.79$ to 1.18 ), whereas the Val/ $\mathrm{Val}$ genotype was associated with a reduced risk (OR 0.63 , $95 \% \mathrm{Cl} 0.42$ to 0.92 ). This inverse association seemed strongest in older women (OR $0.51,95 \% \mathrm{Cl} 0.29$ to 0.89 for women aged more than 55 years), women without a family history of breast cancer (OR $0.54,95 \% \mathrm{Cl} 0.35$ to 0.84 ), postmenopausal women with greater body mass index (OR $0.43,95 \% \mathrm{Cl} 0.20$ to 0.91 for a body mass index of $25.3 \mathrm{~kg} / \mathrm{m}^{2}$ or more), and cases diagnosed with non-localized breast cancer (OR 0.49, 95\% Cl 0.26 to 0.90).

Conclusion Although results from our population-based casecontrol study show an inverse association between the HER2 lle655Val polymorphism and risk of invasive breast cancer, most other studies of this single-nucleotide polymorphism suggest an overall null association. Any further study of this polymorphism should involve sample populations with complete risk factor information and sufficient power to evaluate gene-environment interactions between the HER2 polymorphism and factors such as age and family history of breast cancer.

\section{Introduction}

The proto-oncogene human epidermal growth factor receptor 2 (HER2/neu, also called c-erbB-2) belongs to a family of receptors involved in the tyrosine kinase-mediated regulation of normal breast tissue growth and development [1]. HER2 amplification or overexpression is fairly common - present in 20 to $30 \%$ of human breast cancers - and is a significant predictor of response to therapy, prognosis, and overall survival [1]. HER2 is also a target for therapy. Antibody therapy with trastuzumab, which binds the extracellular portion of HER2, has been associated with improved patient outcomes including survival [2]. Because HER2 clearly has an important role in prognosis after a diagnosis of breast cancer, the gene encoding it is a natural target for investigation regarding polymorphisms that might indicate resistance or susceptibility for breast cancer development. 
One single-nucleotide polymorphism (SNP) at codon 655 indicates a guanine-to-adenine substitution (lle655Val) in the transmembrane domain-coding region of the HER2 gene [3]. This SNP has been evaluated in a variety of populations; studies show that the prevalence of the $\mathrm{Val} / \mathrm{Val}$ genotype ranges from 3\% to $7 \%$ in control women [4-6], although this genotype may be less common or unobserved in people with Asian or African descent [7-9].

Epidemiologic studies of the association between the Ile655Val polymorphism and breast cancer risk have generally shown null associations, with risk estimates below unity $[4,5,10,11]$ and above unity $[6,8,12-14]$. Subgroup analysis in several studies suggested that, among women who were younger [7,8,14], physically inactive [7], had greater body mass [7], or had a positive family history of breast cancer [6,8], the $\mathrm{Val} / \mathrm{Val}$ genotype was associated with an increased risk of breast cancer in comparison with the lle/lle genotype. Further study of this SNP has been supported because of the concern that subgroups of identifiable women might be especially susceptible to breast cancer $[6,10]$. In the present study we evaluated the association between the HER2 lle655Val polymorphism and breast cancer risk in a population-based case-control study of midwestern United States women.

\section{Materials and methods Study subjects}

As part of a continuing epidemiologic study, we recruited population-based cases of incident invasive breast cancer as well as community controls across Wisconsin in accordance with a protocol approved by the University of Wisconsin Health Sciences Human Subjects Committee. Invasive breast cancer cases (excluding carcinoma in situ) aged 20 to 69 years were identified though the Wisconsin statewide tumor registry. Controls were randomly sampled from driver's license files (ages 20 to 64 years) and Medicare beneficiary lists (ages 65 to 69 years); controls were frequency-matched in 5-year intervals to have a similar age distribution to that of the cases. All participants were required to have an available telephone number, and controls who self-reported a personal history of breast cancer were not eligible. Before April 2003, when changes in federal law affected the willingness of physicians to acknowledge their care of our eligible participants, physicians (identified on the tumor registry reports) were contacted before case enrollment to obtain information that might contraindicate study participation, such as dementia. All cases and controls were contacted by mail before receiving an interviewer's call. The 35-minute structured telephone interview elicited complete reproductive and menstrual histories, exogenous hormone use, smoking history, recent alcohol use and recreational physical activity, lifetime occupational and residential history, and exposure to indoor and outdoor chemicals. Information regarding the women's personal and family history of cancer was obtained at the end of the interview to maintain interviewer blinding. During April 2001 to January 2004, 77\% of eligible cases $(N=1,884)$ and $70 \%$ of eligible controls ( $N$ $=2,146$ ) participated in the telephone interview. The major reasons for nonparticipation were refusal ( $15 \%$ of cases, $23 \%$ of controls), death before the interview ( $2 \%$ of cases, $1 \%$ of controls), and inability to locate (3\% of cases, $6 \%$ of controls). Before April 2003, physicians refused participation for $2 \%$ of cases.

At the conclusion of the telephone interview, all cases and controls were asked to provide a mouthwash rinse. Those agreeing were mailed a kit containing a $44 \mathrm{ml}$ bottle of Scope mouthwash, consent forms, prepaid return mailing supplies, and other all materials needed for producing the sample. During April 2001 to January 2004, samples were obtained from $1,482$ cases $(79 \%)$ and 1,727 controls ( $81 \%)$. Genomic DNA was extracted by using the Gentra Systems DNA extraction reagents and protocol. DNA was resuspended in sterile water. Samples contained an average yield of $29.3 \mu \mathrm{g}$ of DNA.

\section{Genotyping}

The laboratory staff were blinded to the identity and disease status of the subjects. Samples were genotyped for the HER2 Ile655Val polymorphism with the Applied Biosystems allelic discrimination assay-by-design (no. 185078430). The primers and labeled oligonucleotide probes for this reaction were as follows: forward, 5'-CCTGACCCTGGCTTCCG-3' ; reverse, 5'-ACCAGCAGAATGCCAACCA-3'; VIC probe (detects T), 5'-ACGTCCATCATCTC-3' ; FAM probe (detects C), 5'CCATCGTCTCTGCG-3'. Samples were cycled with conditions recommended by $\mathrm{ABI}$. Fluorescence was detected with the ABI 7700 and genotypes were called manually with the detection software for this instrument. Genotyping failed for 45 subjects (2\%). For quality control, DNA from 79 subjects who had submitted two independent samples were genotyped; $100 \%$ (79 of 79 ) had identical genotypes for the two samples. HER2 genotype was obtained for the 1,098 invasive breast cancer cases and 991 controls with European descent who had mailed their mouthwash samples to study staff by 30 June 2003. Because of the small number of women with nonEuropean descent (46 cases, 55 controls) and the low prevalence of the HER2 Val/Val genotype in Asian and African populations, these women were not genotyped.

\section{Statistical analysis}

Only exposure status before an assigned reference date was used in this analysis. For cases, this was the date of breast cancer diagnosis. For comparability, control subjects were assigned a reference date corresponding to the average time from diagnosis to interview for the case group (about 1 year). The reference age was defined as the age at the reference date. Menopausal status was defined as postmenopausal if the subject reported natural menopause or bilateral oophorectomy before the reference date. Women reporting hysterectomy alone were classified as postmenopausal if their reference age was greater than or equal to the 90th centile of 
Table 1

\section{Characteristics of invasive breast cancer cases and population controls, Wisconsin, 2001 to 2003}

\begin{tabular}{ccccc}
\hline Characteristic & \multicolumn{2}{c}{ Cases $(N=1,094)$} & Controls $(N=976)$ & $\mathrm{OR}^{+}$ \\
$n^{*}$ & $n^{*}$ & $95 \% \mathrm{Cl}^{+}$
\end{tabular}

Family history of breast cancer

Absent

Present

Unknown

Recent alcohol consumption

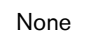

1 drink/week

2-6 drinks/week

7 or more drinks/week

Parity

0-1

2

3

4 or more

Menopausal status

Postmenopausal

Premenopausal

Unknown

Age at menopause (years) ${ }^{\ddagger}$

$<45$

45-49

50-54

$55+$

Unknown

Body mass index $\left(\mathrm{kg} / \mathrm{m}^{2}\right)^{\ddagger}$

$<22.6$

22.6-25.2

25.3-28.9

$29.0+$

Weight change since age $18(\mathrm{~kg})^{\ddagger}$

Lost 5 or more

Lost 5 to gained 4

Gained 5 to 11

Gained 12 to 21

Gained 22 or more

HRT use ${ }^{\ddagger}$

Never

Former

Current

Age at menarche (years)

\section{2}

21.1

0.7

14.0

38.8

35.2

12.1

23.9

35.8

23.1

17.1

54.6

37.9

7.5

23.1

18.9

34.3

11.4

12.2

21.6

24.1

27.8

25.6

153

14

95

148

179

154

184

45

368
2.3

15.9

24.8

30.0

25.8

30.8

7.5

61.6
829

132

15

166

418

270

122

217

275

209

275

592

313

71

175

127

172

65

53

135

136

161

156

20

109

140

172

143

233

77

282
85.3

13.1

1.7

16.8

42.5

28.2

12.4

23.4

29.7

21.3

25.6

55.1

36.8

8.1

30.1

21.4

29.0

10.1

9.4

23.1

22.8

26.8

26.6

3.5

18.9

23.3

28.7

24.3

37.9

12.6

49.4
1 (Reference)

$\begin{array}{ll}1.69 & 1.33-2.16 \\ 0.44 & 0.18-1.05\end{array}$

1 (Reference)

$\begin{array}{ll}1.10 & 0.84-1.45 \\ 1.57 & 1.19-2.09 \\ 1.23 & 0.87-1.74\end{array}$

1 (Reference)

$\begin{array}{ll}1.22 & 0.95-1.55 \\ 0.99 & 0.76-1.30 \\ 0.58 & 0.44-0.77\end{array}$

1 (Reference)

$1.25 \quad 0.92-1.70$

$1.06 \quad 0.71-1.58$

1 (Reference)

$\begin{array}{ll}1.15 & 0.80-1.65 \\ 1.61 & 1.16-2.23 \\ 1.42 & 0.91-2.20 \\ 1.76 & 1.14-2.77\end{array}$

(Reference)

$\begin{array}{ll}1.18 & 0.82-1.69 \\ 1.09 & 0.77-1.54 \\ 0.97 & 0.69-1.38\end{array}$

$0.92 \quad 0.42-2.03$

1 (Reference)

$1.42 \quad 0.97-2.09$

$1.30 \quad 0.90-1.88$

$1.32 \quad 0.91-1.93$

1 (Reference)

$0.65 \quad 0.42-1.01$

$1.49 \quad 1.14-1.95$ 
Table 1 (Continued)

\begin{tabular}{|c|c|c|c|c|c|c|}
\hline$<12$ & 228 & 20.8 & 176 & 18.1 & \multicolumn{2}{|c|}{1 (Reference) } \\
\hline 12 & 282 & 25.8 & 253 & 26.4 & 0.83 & $0.64-1.09$ \\
\hline 13 & 297 & 27.1 & 244 & 24.4 & 0.94 & $0.72-1.23$ \\
\hline 14 & 183 & 16.7 & 172 & 17.6 & 0.81 & $0.61-1.10$ \\
\hline $15+$ & 98 & 9.0 & 119 & 12.4 & 0.63 & $0.45-0.89$ \\
\hline \multicolumn{7}{|c|}{ Height at age $25(\mathrm{~m})$} \\
\hline$<1.60$ & 198 & 18.1 & 218 & 21.9 & \multicolumn{2}{|c|}{1 (Reference) } \\
\hline $1.60-1.64$ & 295 & 27.0 & 263 & 27.0 & 1.25 & $0.96-1.62$ \\
\hline $1.65-1.67$ & 299 & 27.3 & 264 & 26.9 & 1.26 & $0.97-1.64$ \\
\hline $1.68+$ & 302 & 27.6 & 231 & 24.1 & 1.47 & $1.12-1.92$ \\
\hline
\end{tabular}

${ }^{*}$ Control percentages are age-adjusted to the distribution of cases; ${ }^{+}$logistic regression models conditional on age; ${ }^{*}$ among postmenopausal women. $\mathrm{Cl}$, confidence interval; HRT, hormone replacement therapy; OR, odds ratio.

age at natural menopause for the control group (54 years for smokers and 56 years for nonsmokers). Menopausal status was considered to be unknown for women with hysterectomy without bilateral oophorectomy if their reference age was between 42 and 54 years (or 56 years for nonsmokers).

Adjusted odds ratios (ORs) and 95\% confidence intervals (Cls) were obtained from multivariable conditional logistic regression models stratified on age. Covariates for the models were chosen by forward stepwise regression $\left(P_{\text {entry }}=0.20\right.$, $P_{\text {removal }}=0.30$ ). After forward stepwise regression had been performed, covariates remaining in the model were: family history of breast cancer in a mother, daughter, or sister (yes, no, unknown), recent alcohol consumption (four categories), parity (four categories), menopausal status and age at menopause (four categories of age at menopause, premenopausal, unknown), hormone replacement therapy use (never, former, current), age at menarche (five categories of age, plus unknown), height at age 25 years (continuous), weight at age 18 years (continuous) and weight change since age 18 years (five categories). Covariates that did not remain in the final model included age at first birth, education, and income. Women with unknown recent alcohol consumption, hormone replacement therapy use, or height at age 25 years were not included in the analysis (4 cases, 15 controls), so that 1,094 cases and 976 controls remained in the analysis. Interactions with genotype in relation to breast cancer risk were evaluated by including a cross-product term in the regression model and measuring the change in the log-likelihood.

\section{Results}

Breast cancer cases were more likely than controls to report a positive family history of breast cancer, to drink modest amounts of alcohol, to have lower parity, to report menopause at later ages, to have a younger age at menarche, and to report taller adult height (Table 1). Cases in this HER2 analysis were slightly less likely to have non-localized breast cancer at diagnosis; $32 \%$ of cases who contributed buccal samples that were included in the HER2 analysis had regional or distantstaged disease at diagnosis, whereas $37 \%$ of cases who refused to contribute a sample had non-localized disease $(N=$ 356, $P=0.07$ by Fisher's exact test). Participants in this analysis were similar to nonparticipants in body mass index $(P=$ 0.14 for cases, $P=0.29$ for controls by $t$-test; $N=442$ nonparticipant controls) and family history of breast cancer $(P=$ 0.27 for cases, $P=0.36$ for controls by Fisher's exact test), although control participants were somewhat older (55 versus 53 years, $P=0.02$ by $t$-test) and more likely to have attended college than nonparticipant controls (56\% versus 50\%, $P=$ 0.05 by Fisher's exact test). Among cases, participants in this analysis did not differ significantly from nonparticipants in age (54 versus 53 years, $P=0.73$ ) but were slightly more likely to have attended college (57\% versus $52 \%, P=0.09$ ).

The Ile allele frequency was similar for cases and controls (cases $76.3 \%, 95 \% \mathrm{Cl} 74.5$ to $78.1 \%$; controls $74.7 \%, 95 \%$ $\mathrm{Cl} 72.8$ to $76.6 \%$ ), and the Val allele frequency was about $25 \%$ (cases $23.7 \%, 95 \%$ Cl 21.9 to $25.5 \%$; controls $25.3 \%$, $95 \% \mathrm{Cl} 23.4$ to $27.2 \%$ ); $58.2 \%$ of cases and $56.5 \%$ of controls were homozygous for the lle allele, $36.2 \%$ of cases and $36.5 \%$ of controls were heterozygous, and $5.6 \%$ of cases and $7.1 \%$ of controls were homozygous for the Val allele (Table 2 ). Both the case group $(P=0.96)$ and the control group $(P=$ 0.28 ) were consistent with Hardy-Weinberg equilibrium.

After multivariable adjustment, the combined Ile/Val and Val/ Val genotypes were not significantly associated with a risk of breast cancer relative to two copies of the lle allele (OR 0.90, $95 \% \mathrm{Cl} 0.75$ to 1.09 ; Table 2). The presence of two copies of the $\mathrm{Val}$ allele was associated with a $37 \%$ reduced risk of breast cancer compared with the lle/lle genotype (OR 0.63, $95 \% \mathrm{Cl} 0.42$ to 0.92 ). Whereas this inverse association was suggested for cases diagnosed with localized breast cancer (OR $0.69,95 \% \mathrm{Cl} 0.45$ to 1.06 ), the OR was significantly reduced for cases diagnosed with regional or distant metastasis (OR $0.49,95 \% \mathrm{Cl} 0.26$ to 0.90 ). 
Table 2

\begin{tabular}{|c|c|c|c|c|c|c|c|c|}
\hline \multirow[t]{2}{*}{ Polymorphism } & \multicolumn{2}{|c|}{ Cases } & \multicolumn{2}{|c|}{ Controls } & \multirow[t]{2}{*}{$\mathrm{OR}^{*}$} & \multirow[t]{2}{*}{$95 \% \mathrm{Cl}^{*}$} & \multirow[t]{2}{*}{$\mathrm{OR}^{+}$} & \multirow[t]{2}{*}{$95 \% \mathrm{Cl}^{+}$} \\
\hline & $N$ & $\%$ & $N$ & $\%$ & & & & \\
\hline \multicolumn{9}{|l|}{ All subjects } \\
\hline Ile/lle & 637 & 58.2 & 551 & 56.5 & \multicolumn{2}{|c|}{1 (Reference) } & \multicolumn{2}{|c|}{1 (Reference) } \\
\hline Ile/Val or $\mathrm{Val} / \mathrm{Val}$ & 457 & 41.8 & 425 & 43.5 & 0.92 & $0.76-1.10$ & 0.90 & $0.75-1.09$ \\
\hline lle/Val & 396 & 36.2 & 356 & 36.5 & 0.96 & $0.79-1.16$ & 0.97 & $0.79-1.18$ \\
\hline $\mathrm{Val} / \mathrm{Val}$ & 61 & 5.6 & 69 & 7.1 & 0.71 & $0.49-1.04$ & 0.63 & $0.42-0.92$ \\
\hline \multicolumn{9}{|l|}{ Localized disease $^{\ddagger}$} \\
\hline Ile/lle & 425 & 58.5 & 551 & 56.5 & \multicolumn{2}{|c|}{1 (Reference) } & \multicolumn{2}{|c|}{1 (Reference) } \\
\hline lle/Val or $\mathrm{Val} / \mathrm{Val}$ & 301 & 41.5 & 425 & 43.5 & 0.91 & $0.74-1.12$ & 0.90 & $0.73-1.12$ \\
\hline Ile/Val & 257 & 35.4 & 356 & 36.5 & 0.94 & $0.76-1.16$ & 0.95 & $0.76-1.19$ \\
\hline $\mathrm{Val} / \mathrm{Val}$ & 44 & 6.1 & 69 & 7.1 & 0.78 & $0.52-1.18$ & 0.69 & $0.45-1.06$ \\
\hline \multicolumn{9}{|c|}{ Regional or distant metastasis ${ }^{\ddagger}$} \\
\hline Ile/lle & 195 & 57.5 & 551 & 56.5 & \multicolumn{2}{|c|}{1 (Reference) } & \multicolumn{2}{|c|}{1 (Reference) } \\
\hline lle/Val or $\mathrm{Val} / \mathrm{Val}$ & 144 & 42.5 & 425 & 43.5 & 0.96 & $0.74-1.25$ & 0.96 & $0.73-1.27$ \\
\hline Ile/Val & 128 & 37.8 & 356 & 36.5 & 1.03 & $0.79-1.36$ & 1.08 & $0.81-1.44$ \\
\hline $\mathrm{Val} / \mathrm{Val}$ & 16 & 4.7 & 69 & 7.1 & 0.60 & $0.34-1.09$ & 0.49 & $0.26-0.90$ \\
\hline
\end{tabular}

*Logistic regression models conditional on age; +logistic regression models conditional on age and adjusted for family history of breast cancer, recent alcohol consumption, parity, menopausal status, age at menopause, hormone replacement therapy use, age at menarche, height at age 25 years, weight at age 18 years, and weight change since age 18 years; ffor cases at diagnosis. Cl, confidence interval; OR, odds ratio.

Although no interactions between the HER2 polymorphism and common risk factors were statistically significant, the inverse association with breast cancer risk was strongest in some subgroups (Table 3). In particular, ORs were significantly reduced for women at older ages (more than 55 years), without a family history of breast cancer, with older age at menarche, currently using postmenopausal hormones, with greater recent body mass index, and women with greater weight gain since age 18 years. In addition, we could not find evidence to support heterogeneity in the association between the HER2 lle655Val polymorphism and breast cancer risk according to recent physical activity $(P=0.45)$, cigarette smoking status $(P=0.66)$, adult height $(P=0.78)$, recent alcohol intake $(P=0.83)$, parity $(P=0.81)$, or age at menopause $(P=0.41)$ (data not shown).

\section{Discussion}

We observed a 40 to $50 \%$ decreased risk of breast cancer associated with the inheritance of two HER2 valine alleles at codon 655 for some subgroups of women, including women older than 55 years of age and women without a family history of breast cancer. Three other studies - one study of Asian women [11] and two studies of women with European descent $[4,5,10]$ - have also reported decreased risk estimates of breast cancer associated with inheritance of the HER2 Val allele, although the estimates from these three other studies were not statistically significant.
Our null results for younger women and women with a positive family history of breast cancer do not concur with findings by Montgomery and colleagues [14], which showed a threefold increased risk among Australian women less than 40 years of age. Wang-Gohrke and Chang-Claude [6] reported a twofold increased risk among German Caucasians with a first-degree family history of breast cancer. Similarly, Millikan and colleagues [8] reported a twofold increased risk of breast cancer associated with the $\mathrm{Val} / \mathrm{Val}$ or $\mathrm{Val} / \mathrm{ll}$ e genotype (compared with the lle/lle genotype) among women living in North Carolina (United States) who were both less than 45 years of age and reported a positive family history of breast cancer (OR 2.3, $95 \% \mathrm{Cl} 1.0$ to 5.3). We were limited in our ability to examine the HER2 polymorphism in younger women because of small numbers. Only 4 controls and 12 cases in our study were 45 years of age or younger, reported a positive family history of breast cancer, and also had the $\mathrm{Val} / \mathrm{Val}$ or $\mathrm{Val} / \mathrm{lle}$ genotype (OR 1.44, 95\% Cl 0.21 to 9.79 , with lle/lle as the reference category; data not shown).

The first study of the HER2 lle655Val polymorphism in relation to breast cancer risk found a very high risk (OR 14.1, 95\% Cl 1.8 to 113.4 ) of the $\mathrm{Val} / \mathrm{Val}$ versus lle/lle genotype [7]. In that study, the $\mathrm{Val} / \mathrm{Val}$ genotype was detected in only 11 cases and 1 control. Risk estimates in subsequent studies have been much more modest, ranging from 0.3 to 2.8 , and our results clearly fall within this (wide) range. Although risk estimates 
Table 3

Risk of invasive breast cancer according to the HER2 Ile655Val polymorphism and common risk factors

\begin{tabular}{|c|c|c|c|c|c|}
\hline \multirow[t]{2}{*}{ Risk factor* } & \multicolumn{5}{|c|}{ HER2 polymorphism } \\
\hline & Ile/lle, cases/controls & $\mathrm{Val} / \mathrm{Val}$, cases/controls & lle/lle, $\mathrm{OR}^{\dagger}, 95 \% \mathrm{Cl}$ & $\mathrm{Val} / \mathrm{Val}, \mathrm{OR}^{\dagger}(95 \% \mathrm{Cl})$ & $P^{\ddagger}$ \\
\hline Age (years) & & & & & 0.29 \\
\hline$<55$ & $317 / 256$ & $32 / 29$ & 1 (reference) & $0.78(0.44-1.37)$ & \\
\hline $55+$ & $320 / 295$ & $29 / 40$ & 1 (reference) & $0.51(0.29-0.89)$ & \\
\hline $\begin{array}{l}\text { Family history of breast } \\
\text { cancer }\end{array}$ & & & & & 0.24 \\
\hline None & $505 / 461$ & $41 / 59$ & 1 (reference) & $0.54(0.35-0.84)$ & \\
\hline Any & $128 / 79$ & $19 / 10$ & 1 (reference) & $0.92(0.32-2.62)$ & \\
\hline Age at menarche (years) & & & & & 0.14 \\
\hline$<13$ & $288 / 249$ & $32 / 35$ & 1 (reference) & $0.88(0.50-1.54)$ & \\
\hline$\geq 13$ & $346 / 297$ & $29 / 33$ & 1 (reference) & $0.47(0.27-0.84)$ & \\
\hline HRT use§ & & & & & 0.19 \\
\hline Never/former & $149 / 169$ & $12 / 10$ & 1 (reference) & $1.24(0.46-3.39)$ & \\
\hline Current & $212 / 163$ & $18 / 23$ & 1 (reference) & $0.46(0.22-0.97)$ & \\
\hline Recent body mass index $\S$ & & & & & 0.07 \\
\hline$<25.3 \mathrm{~kg} / \mathrm{m}^{2}$ & $159 / 166$ & $14 / 10$ & 1 (reference) & $1.01(0.39-2.64)$ & \\
\hline$\geq 25.3 \mathrm{~kg} / \mathrm{m}^{2}$ & $196 / 163$ & $14 / 25$ & 1 (reference) & $0.43(0.20-0.91)$ & \\
\hline $\begin{array}{l}\text { Weight change since age } \\
18 \text { years }(\mathrm{kg})^{\S}\end{array}$ & & & & & 0.12 \\
\hline Lost 5 to gained 11 & $142 / 148$ & $14 / 11$ & 1 (reference) & $1.04(0.41-2.67)$ & \\
\hline Gained 12 or more & $204 / 164$ & $14 / 22$ & 1 (reference) & $0.44(0.20-0.98)$ & \\
\hline
\end{tabular}

*Risk factor cut-points based on the approximate median values for the controls; ${ }^{\dagger}$ logistic regression models conditional on age and, as appropriate, adjusted for family history of breast cancer, recent alcohol consumption, parity, menopausal status, age at menopause, hormone replacement therapy use, age at menarche, height at age 25 years, weight at age 18 years, and weight change since age 18 years; ${ }^{*} P$ interaction using the likelihood ratio test and assuming a multiplicative model (risk factors parameterized as dichotomous variables as shown in the table for purposes of the interaction tests); § postmenopausal women only. Cl, confidence interval; HRT, hormone replacement therapy; OR, odds ratio.

have suggested both inverse and positive associations with breast cancer risk, prevalence of the $\mathrm{Val} / \mathrm{Val}$ genotype has consistently been 3 to $8 \%$ in breast cancer cases and 3 to $7 \%$ in controls in women with European descent. Allele frequencies for case and control women corresponding to the $\mathrm{Val} / \mathrm{Val}$ genotype in our study are very similar to frequencies reported in three other studies of white women in North Carolina, southeast England, and Germany - ranging from 23\% to 25\% - and slightly higher than frequencies for control women in two other studies conducted in Australia and New York City (18.7\% and $16 \%$, respectively) $[5,6,8,13,14]$.

Most studies of the HER2 lle655Val polymorphism have used a case-control design. Only one study population was a prospective cohort [12]. Two other published reports used a kincohort approach $[15,16]$. Using this novel design with a study of 1,560 volunteers living in Washington DC and Israel, Rutter and colleagues [16] reported that the HER2 valine allele might be associated with a twofold to eightfold increased risk of breast cancer. As with the Millikan study [8], these increased risks were confined to younger women with a family history of breast cancer.

Many studies of the HER2 lle655Val polymorphism had insufficient power to evaluate interactions between the SNP and subgroups according to risk factors such as age and family history of breast cancer. Limited power is a common problem in studies of genetic polymorphisms. Sample size for only one other study was larger than the case and control enrollment in our own study [8]. Prevalence of the lle655Val polymorphism clearly varies according to racial descent - it is rare or unobserved in Asian and African populations [9,17] - further limiting statistical power to evaluate the significance or relevance of this SNP in different populations. Stratified analysis of the HER2 lle655Val genotype according to racial descent is warranted.

Potential limitations might have influenced our findings. Although participation in our study was excellent for a population-based case-control study, certain subgroups might have been under-represented because participation probably 
declines with increasing age, decreasing attained education, and other factors. However, genetic inheritance with the HER2 gene is probably not confounded with the variables that might influence a woman's participation in our epidemiologic study [18]. The distribution of the HER2 polymorphism in our case and control groups was consistent with Hardy-Weinberg equilibrium, which suggests that any genotyping errors were not substantial. Duplicate genotyping of 79 samples was also reassuring, achieving 100\% concordance.

The mechanism through which this SNP might influence breast cancer risk is unclear, although studies in transgenic mice have demonstrated that activation or overexpression of the HER2 gene leads to the development of mammary adenocarcinomas [19-21]. The transmembrane domain of the HER2 protein might be especially important, given the discovery of an activating mutation in codon 664 in the rat [22-25]. In humans, the lle655Val amino acid substitution might alter the formation of active HER2 dimers, which would then alter the activity of the protein [26].

\section{Conclusion}

These data from our sample population of white women from the midwestern United States suggest that the $\mathrm{Val} / \mathrm{Val}$ genotype of the HER2 lle655Val polymorphism is associated with a reduced risk of breast cancer in comparison with the lle/lle genotype for some women. Although the sample size in our study was relatively large compared with other studies published so far, the inconsistency of the findings across all studies argues against a strong relation with breast cancer risk. Future large studies of the HER2 polymorphism might clarify this putative gene-environment interaction. However, given the promise of innovative and more comprehensive approaches to genomic and proteomic studies of breast cancer risk, focusing on this SNP without consideration of the role of other genes and polymorphisms may not be warranted.

\section{Competing interests}

The author(s) declare that they have no competing interests.

\section{Authors' contributions}

SEN performed the processing and genotyping of the samples and drafted the manuscript. MNG and ATD jointly conceived of and designed the study, obtained funding, and drafted the manuscript. JMH performed the statistical analysis and assisted with manuscript preparation. All authors read and approved the final manuscript.

\section{Acknowledgements}

We thank Dr Patrick Remington, Dr Henry Anderson, Dr Polly Newcomb, and Dr Jane McElroy for support throughout this project; Laura Stephenson and the staff of the Wisconsin Cancer Reporting System; Katie Nelson, Jill Haag, Don Wigington, and Yu-Rong Wang for laboratory assistance; Susan Carlson, Lisa Sieczkowski, Emogene Dodsworth, Betty Granda, Liz Mannering, Kathy Peck, Christina Kantor, and Jan Langdon for data collection; and Amy Sapp, Mary Pankratz, Jerry
Phipps, Jeff Pearson, and Lene Dotzler for technical support on this project. This project was supported in part by National Cancer Institute grants CA82004, CA28954, and CA77494, Department of Defense grant DAMD1 7-01-1-0459, and a gift from the Fraternal Order of Eagles Arie no. 1502 to the University of Wisconsin Comprehensive Cancer Center.

\section{References}

1. Cooke T, Reeves J, Lanigan A, Stanton P: HER2 as a prognostic and predictive marker for breast cancer. Ann Oncol 2001, 12(Suppl 1):S23-S28.

2. Ross JS, Fletcher JA, Linette GP, Stec J, Clark E, Ayers M, Symmans WF, Pusztai L, Bloom KJ: The Her-2/neu gene and protein in breast cancer 2003: biomarker and target of therapy. Oncologist 2003, 8:307-325.

3. Papewalis J, Nikitin A, Rajewsky MF: G to A polymorphism at amino acid codon 655 of the human erbB-2/HER2 gene. Nucleic Acids Res 1991, 19:5452.

4. Zheng W, Kataoka N, Xie D, Young SR: Response: Re: Population-based, case-control study of HER2 genetic polymorphism and breast cancer risk. J Nat/ Cancer Inst 2001, 93:558-559.

5. Baxter SW, Campbell IG: Re: Population-based, case-control study of HER2 genetic polymorphism and breast cancer risk. $J$ Natl Cancer Inst 2001, 93:557-559.

6. Wang-Gohrke S, Chang-Claude J: Re: Population-based, casecontrol study of HER2 genetic polymorphism and breast cancer risk. J Natl Cancer Inst 2001, 93:1657-1659.

7. Xie D, Shu XO, Deng Z, Wen WQ, Creek KE, Dai Q, Gao YT, Jin F, Zheng W: Population-based, case-control study of HER2 genetic polymorphism and breast cancer risk. J Natl Cancer Inst 2000, 92:412-417.

8. Millikan R, Eaton A, Worley K, Biscocho L, Hodgson E, Huang WY, Geradts J, lacocca M, Cowan D, Conway K, et al.: HER2 codon 655 polymorphism and risk of breast cancer in African Americans and whites. Breast Cancer Res Treat 2003, 79:355-364.

9. Ameyaw MM, Thornton N, McLeod HL: Re: population-based, case-control study of HER2 genetic polymorphism and breast cancer risk. J Natl Cancer Inst 2000, 92:1947.

10. Zheng W, Wen W-Q: Response: Re: Population-based, casecontrol study of HER2 genetic polymorphism and breast cancer risk. J Natl Cancer Inst 2001, 93:1658-1659.

11. Hishida A, Hamajima N, Iwata H, Matsuo K, Hirose K, Emi N, Tajima K: Re: Population-based, case-control study of HER2 genetic polymorphism and breast cancer risk. J Natl Cancer Inst 2002, 94:1807-1808.

12. McKean-Cowdin R, Kolonel LN, Press MF, Pike MC, Henderson BE: Germ-line HER-2 variant and breast cancer risk by stage of disease. Cancer Res 2001, 61:8393-8394.

13. Keshava C, McCanlies EC, Keshava N, Wolff MS, Weston A: Distribution of HER2(V655) genotypes in breast cancer cases and controls in the United States. Cancer Lett 2001, 173:37-41.

14. Montgomery KG, Gertig DM, Baxter SW, Milne RL, Dite GS, McCredie MR, Giles GG, Southey MC, Hopper JL, Campbell IG: The HER2 $1655 \mathrm{~V}$ polymorphism and risk of breast cancer in women < age 40 years. Cancer Epidemiol Biomarkers Prev 2003, 12:1109-1111.

15. Hauptmann M, Sigurdson AJ, Chatterjee N, Rutter JL, Hill DA, Doody MM, Struewing JP: Re: Population-based, case-control study of HER2 genetic polymorphism and breast cancer risk. $J$ Natl Cancer Inst 2003, 95:1251-1252.

16. Rutter JL, Chatterjee N, Wacholder S, Struewing J: The HER2 $1655 \mathrm{~V}$ polymorphism and breast cancer risk in Ashkenazim. Epidemiology 2003, 14:694-700.

17. Ameyaw MM, Tayeb M, Thornton N, Folayan G, Tariq M, Mobarek A, Evans DA, Ofori-Adjei D, McLead HL: Ethnic variation in the HER-2 codon 655 genetic polymorphism previously associated with breast cancer. J Hum Genet 2002, 47:172-175.

18. Morimoto LM, White E, Newcomb PA: Selection bias in the assessment of gene-environment interaction in case-control studies. Am J Epidemio/ 2003, 158:259-263.

19. Guy CT, Webster MA, Schaller M, Parsons TJ, Cardiff RD, Muller WJ: Expression of the neu protooncogene in the mammary epithelium of transgenic mice induces metastatic disease. Proc Natl Acad Sci USA 1992, 89:10578-10582. 
20. Muller WJ, Sinn E, Pattengale PK, Wallace R, Leder P: Singlestep induction of mammary adenocarcinoma in transgenic mice bearing the activated c-neu oncogene. Cell 1988, 54:105-115.

21. Bouchard L, Lamarre L, Tremblay PJ, Jolicoeur P: Stochastic appearance of mammary tumors in transgenic mice carrying the MMTV/c-neu oncogene. Cell 1989, 57:931-936.

22. Cao H, Bangalore L, Bormann BJ, Stern DF: A subdomain in the transmembrane domain is necessary for $\mathrm{p} 185 \mathrm{neu}^{*}$ activation. EMBO J 1992, 11:923-932.

23. Segatto O, King CR, Pierce JH, Di Fiore PP, Aaronson SA: Different structural alterations upregulate in vitro tyrosine kinase activity and transforming potency of the erbB-2 gene. Mol Cell Biol 1988, 8:5570-5574.

24. Sternberg MJ, Gullick WJ: Neu receptor dimerization. Nature 1989, 339:587.

25. Sternberg MJ, Gullick WJ: A sequence motif in the transmembrane region of growth factor receptors with tyrosine kinase activity mediates dimerization. Protein Eng 1990, 3:245-248.

26. Fleishman SJ, Schlessinger J, Ben-Tal N: A putative molecularactivation switch in the transmembrane domain of erbB2. Proc Natl Acad Sci USA 2002, 99:15937-15940. 